\title{
HUBUNGAN PERAN PENGAWAS MENELAN OBAT (PMO) TERHADAP KEBERHASILAN PENGOBATAN TUBERKULOSIS DI PUSKESMAS KECAMATAN JOHAR BARU JAKARTA PUSAT TAHUN 2016
}

\author{
Wahyuni Herda ${ }^{1}$, Insan Sosiawan A. Tunru ${ }^{2}$, Yusnita ${ }^{3}$ \\ ${ }^{1}$ Fakultas Kedokteran Universitas YARSI \\ ${ }^{2}$ Bagian Patologi Anatomi, Fakultas Kedokteran Universitas YARSI \\ ${ }^{3}$ Bagian Ilmu Kesehatan Masyarakat, Fakultas Kedokteran Universitas YARSI \\ Email : herda.wahyuni@ymail.com
}

\begin{abstract}
ABSTRAK
Tuberkulosis merupakan penyakit yang menjadi perhatian global. Pada tahun 2015 enam negara yang menyumbang untuk 60\% dari total global adalah India, Indonesia, Cina, Nigeria, Pakistan, dan Afrika Selatan. Dari jumlah tersebut, China, India dan Indonesia sendiri menyumbang 45\% kasus di dunia. World Health Organization (WHO) telah merekomendasikan strategi Directly Observed Treatment Shortcourse (DOTS) untuk pengendalian TB dengan melibatkan Pengawas Minum Obat (PMO). Hal ini bertujuan untuk mencapai kesembuhan penderita, mencegah penularan, dan menghindari kasus resisten obat. Penelitian ini bertujuan untuk mengetahui hubungan peran pengawas menelan obat (PMO) terhadap keberhasilan pengobatan tuberkulosis di Puskesmas Kecamatan Johar Baru Jakarta Pusat tahun 2016. Penelitian ini dilakukan dengan metode kuantitatif non-eksperimental secara Cross-Sectional. Populasi dan sampel adalah pasien TB paru dan ekstraparu dewasa di Puskesmas Kecamatan Johar Baru Jakarta Pusat tahun 2016. Sampel dipilih dengan menggunakan Simple Random Sampling. Pengambilan data dilakukan dengan cara wawancara menggunakan kuisioner. Analisis data menggunakan SPSS dengan uji Chi-Square. Terdapat 45 responden $(80,4 \%)$ berhasil dalam pengobatan TB dan responden dengan PMO kategori berperan terdapat 40 (71,4\%). Hasil uji statistik menggunakan uji ChiSquare didapatkan nilai $\mathrm{P}=1,000(>0,05)$. Tidak ada hubungan peran pengawas menelan obat $(\mathrm{PMO})$ terhadap keberhasilan pengobatan tuberkulosis di Puskesmas Kecamatan Johar Baru Jakarta Pusat tahun 2016.
\end{abstract}

Kata Kunci: Pengawas menelan obat (PMO); Keberhasilan pengobatan TB; Tuberkulosis

\begin{abstract}
Tuberculosis is a disease of global concern. By 2015 six countries contributing to 60\% of the global total are India, Indonesia, China, Nigeria, Pakistan and South Africa. China, India and Indonesia alone accounted for 45\% of cases in the world. The World Health Organization (WHO) has recommended the Directly Observed Treatment Shortcourse (DOTS) strategy for TB control by involving Drug Supervisors (PMO). It aims to achieve patient recovery, prevent transmission, and avoid drug resistant cases. This study aims to determine the relation between the roles of treatment observers (PMO) with the success of tuberculosis treatment at community health center of Johar Baru Central Jakarta in 2016. This research was conducted by Cross-Sectional nonexperimental quantitative method. Population and sample are the patient of adult pulmonary and extrapulmonary tuberculosis at community health center of Johar Baru Central Jakarta in 2016. Samples are selected by using Simple Random Sampling. The data were collected by interview using questionnaire. Data analysis using SPSS with Chi-Square test. There were 45 respondents $(80,4 \%)$ succeed in TB treatment and respondent with PMO roles category were $40(71,4 \%)$. Result of statistical test using Chi-Square test obtained $P$ value $=1,000(>0,05)$. There is no relation between the roles of treatment observers $(P M O)$ with the success of tuberculosis treatment at community health center of Johar Baru Central Jakarta in 2016.
\end{abstract}

Keywords: Roles of treatment observers (PMO); Success of tuberculosis treatment; Tuberculosis 


\section{Pendahuluan}

Tuberkulosis merupakan penyakit yang menjadi perhatian global. Dengan berbagai upaya pengendalian yang dilakukan, insidens dan kematian akibat tuberkulosis telah menurun, namun tuberkulosis diperkirakan masih menyerang 9,6 juta orang dan menyebabkan 1,2 juta kematian pada tahun 2014. ${ }^{1}$ Pada tahun 2015, TB adalah salah satu dari 10 penyebab kematian di seluruh dunia, berada diatas HIV/AIDS sebagai salah satu penyebab utama kematian dari penyakit menular. $^{2}$

Insidens di Indonesia berdasarkan hasil survei sejak 2013 terdapat 1 juta kasus per tahun. Persentase jumlah kasus di Indonesia pun menjadi $10 \%$ terhadap seluruh kasus di dunia sehingga menjadi negara dengan kasus terbanyak kedua setelah India. ${ }^{1}$ Pada tahun 2015 terdapat 10,4 juta kasus insiden TB di dunia. Diperkirakan 62\% dari kasus ini adalah laki-laki, dan 90\% dari kasus yang dewasa. Enam negara yang menyumbang untuk $60 \%$ dari total global adalah India, Indonesia, Cina, Nigeria, Pakistan, dan Afrika Selatan. Dari jumlah tersebut, China, India dan Indonesia sendiri menyumbang $45 \%$ kasus di dunia. ${ }^{2}$

Hasil Riset Kesehatan Dasar 2013, tiga provinsi dengan TB paru tertinggi adalah Jawa barat $(0,7 \%)$, Papua $(0,6 \%)$, DKI Jakarta $(0,6 \%))^{3}$ Jumlah penderita TB Paru Klinis (Suspek ditemukan) di Provinsi DKI Jakarta pada tahun 2015 sebanyak 26,499 penderita. Dari jumlah tersebut 5.574 diantaranya merupakan pasien baru TB positif.

Jakarta Timur merupakan wilayah dengan jumlah TB Paru BTA+ terbesar di Provinsi DKI Jakarta yaitu sebanyak 2.058. Pada tahun 2015 setelah dilakukan upaya pengobatan terhadap 5,574 penderita TB Paru BTA+, 96 persen diantaranya dinyatakan sembuh. Berdasarkan persentase kesembuhan, wilayah dengan tingkat keberhasilan pengobatan tertinggi ada di Kota Jakarta Pusat, Jakarta Barat, dan Jakarta Timur. ${ }^{4}$

Penyakit Tuberkolusis dapat disembuhkan dengan pengobatan secara teratur. Keberhasilan pengobatan dipengaruhi beberapa faktor mulai dari karakteristik penderita termasuk status gizi dan imunitas, faktor lingkungan, faktor sarana dan prasarana yang mendukung keteraturan pengobatan. Karena pengobatan TB memerlukan waktu yang sangat panjang dan mungkin menyebabkan kebosanan dan kejenuhan pada penderita. Untuk menjamin keteraturan pengobatan tersebut diperlukan seorang Pengawas Menelan Obat (PMO) yang akan membantu penderita selama dalam program pengobatan $\mathrm{TB}^{5}$

WHO telah merekomendasikan strategi Directly Observed Treatment, Shortcourse (DOTS) untuk pengendalian TB sejak tahun 1995 dengan melibatkan Pengawas Minum Obat (PMO). Peran PMO sangat penting terhadap kepatuhan dan keteraturan minum obat. Hal ini bertujuan untuk mencapai kesembuhan penderita, mencegah penularan, dan menghindari kasus resisten obat. Kolaborasi petugas kesehatan dengan keluarga yang ditunjuk untuk mendampingi penderita, juga faktor yang perlu di evaluasi untuk menentukan tingkat keberhasilannya.

\section{Metode penelitian}

Penelitian ini dilakukan dengan metode kuantitatif non-eksperimental secara CrossSectional. Populasi dan sampel adalah pasien TB paru dan ekstraparu dewasa di Puskesmas Kecamatan Johar Baru Jakarta Pusat tahun 2016. Sampel dipilih dengan menggunakan Simple Random Sampling dan didapatkan jumlah 56 sampel. Sampel yang digunakan memenuhi kriteria inklusi dan eksklusi. Kriteria inklusi pada penelitian ini adalah usia pasien TB paru dan TB ekstra paru $>15$ tahun dan pasien TB paru dan ekstra paru dewasa yang telah menyelesaikan pengobatan OAT selama 6 bulan pada tahun 2016 .

Kriteria eksklusi penelitian ini adalah Pasien TB paru dan ekstra paru yang tidak bersedia mengikuti penelitian. Pengambilan data dilakukan dengan cara wawancara menggunakan kuisioner. Analisis data menggunakan SPSS dengan uji Chi-Square.

\section{Hasil \\ Karakteristik Responden \\ Pada tabel 1. menunjukkan bahwa mayoritas distribusi responden berjenis kelamin laki-laki yaitu 30 orang $(53,6 \%)$.}


Berdasarkan umur sebagian besar responden berumur $>40$ tahun yaitu 29 orang $(51,8 \%)$. Pendidikan responden sebagian besar adalah adalah SD dan SMP yaitu masingmasing berjumlah 18 orang $(32,1 \%)$. Terdapat 28 responden bekerja $(50,0 \%)$ dan sebagian besar hubungan responden dengan pengawas menelan obat (PMO) adalah ibu yaitu 15 orang $(15,8 \%)$.

Tabel 1. Gambaran Pola Distribusi pada Pasien Tuberkulosis di Puskesmas Kecamatan Johar Baru tahun 2016

\begin{tabular}{llcc}
\hline Variabel & \multicolumn{1}{c}{ Kategori } & Jumlah & \% \\
& & & \\
\hline Jenis & Laki-Laki & 30 & 53,6 \\
Kelamin & Perempuan & 26 & 46,4 \\
Umur & $<40$ Tahun & 27 & 48,2 \\
& $>40$ Tahun & 29 & 51,8 \\
Pendidikan & Tidak Tamat SD & 3 & 5,4 \\
& SD & 18 & 32,1 \\
& SMP & 13 & 23,2 \\
& SMA & 18 & 32,1 \\
& Akademi/Sarjana & 4 & 7,1 \\
Pekerjaaan & Bekerja & 28 & 50,0 \\
Status & Tidak Bekerja & 28 & 50,0 \\
PMO & Ibu & 15 & 26,8 \\
& Ayah & 2 & 3,6 \\
& Istri & 11 & 19,6 \\
& Suami & 3 & 5,4 \\
& Anak & 6 & 10,7 \\
& Cucu & 1 & 1,8 \\
& Saudara & 6 & 10,7 \\
& Kader & 9 & 16 \\
& Tidak Ada & 3 & 5,4 \\
\hline
\end{tabular}

\section{Analisis Univariat}

Berdasarkan tabel 2. mengenai gambaran peran pengawas menelan obat (PMO) di Puskesmas Kecamatan Johar Baru Tahun 2016 dari 56 responden didapatkan PMO termasuk kategori berperan adalah 40 $(71,4 \%)$.

Tabel 2. Gambaran Peran Pengawas Menelan Obat (PMO) di Puskesmas Kecamatan Johar Baru Tahun 2016

\begin{tabular}{llcc}
\hline Variabel & Kategori & Jumlah & Persentase \\
\hline Peran & Berperan & 40 & 71,4 \\
PMO & Tidak & 16 & 28,6 \\
& Berperan & & \\
\hline
\end{tabular}

Pada table 3. menunjukkan bahwa distribusi responden menurut keberhasilan pengobatan TB sebagian besar adalah berhasil $45(80,4 \%)$.

Tabel 3. Gambaran Keberhasilan Pengobatan TB di Puskesmas Kecamatan Johar Baru Tahun 2016

\begin{tabular}{llcc}
\hline \multicolumn{1}{c}{ Variabel } & Kategori & Jumlah & Persentase \\
\hline $\begin{array}{l}\text { Keberhasilan } \\
\text { Pengobatan }\end{array}$ & Berhasil & 45 & 80,4 \\
& $\begin{array}{l}\text { Tidak } \\
\text { Berhasil }\end{array}$ & 11 & 19,6 \\
\hline
\end{tabular}

\section{Analisis Bivariat}

Pada tabel 4. menunjukkan bahwa hubungan peran pengawas menelan obat (PMO) terhadap keberhasilan pengobatan tuberkulosis adalah berperan dengan keberhasilan pengobatan sebanyak $32(80 \%)$ sedangkan PMO yang tidak berperan dengan kebehasilan pengobatan sebanyak $13(81,3 \%)$. Hasil uji statistik penelitian ini menggunakan Chi Square didapatkan hasil $\mathrm{P}=1,000(\mathrm{P}>$ $0,05)$. Hal ini menyatakan bahwa $\mathrm{H} 0$ di terima, sehingga berdasarkan hasil uji statistik dapat disimpulkan bahwa tidak ada hubungan peran pengawas menelan obat (PMO) terhadap keberhasilan pengobatan tuberkulosis di Puskesmas Kecamatan Johar Baru tahun 2016.

Tabel 4. Hubungan Peran Pengawas Menelan Obat (PMO)Terhadap Keberhasilan Pengobatan Tuberkulosis di Puskemas Kecamatan Johar Baru Jakarta Pusat Tahun 2016

\begin{tabular}{|c|c|c|c|c|c|}
\hline \multirow{2}{*}{\multicolumn{2}{|c|}{$\begin{array}{c}\text { Peran } \\
\text { Pengawas } \\
\text { Menelan Obat } \\
\text { (PMO) }\end{array}$}} & \multicolumn{2}{|c|}{$\begin{array}{l}\text { Keberhasilan } \\
\text { Pengobatan }\end{array}$} & \multirow{2}{*}{$\begin{array}{l}\text { Tot } \\
\text { al }\end{array}$} & \multirow{2}{*}{$\begin{array}{c}\mathbf{P} \\
\text { valu } \\
\boldsymbol{e}\end{array}$} \\
\hline & & \multirow{2}{*}{\begin{tabular}{|l}
$\begin{array}{l}\text { Berha } \\
\text { sil }\end{array}$ \\
32
\end{tabular}} & \multirow{2}{*}{$\begin{array}{c}\text { Tidak } \\
\text { Berha } \\
\text { sil }\end{array}$} & & \\
\hline $\begin{array}{l}\text { Berper } \\
\text { an }\end{array}$ & $\begin{array}{c}\text { Juml } \\
\text { ah }\end{array}$ & & & 40 & \multirow{6}{*}{$\begin{array}{c}1,00 \\
0\end{array}$} \\
\hline & $\%$ & 80 & 20 & 100 & \\
\hline \multirow{2}{*}{$\begin{array}{l}\text { Tidak } \\
\text { Berper } \\
\text { an }\end{array}$} & $\begin{array}{c}\text { Juml } \\
\text { ah }\end{array}$ & 13 & 3 & 16 & \\
\hline & $\%$ & 81,3 & 18,8 & 100 & \\
\hline \multirow[t]{2}{*}{ Total } & $\begin{array}{c}\text { Juml } \\
\text { ah }\end{array}$ & 45 & 11 & 56 & \\
\hline & $\%$ & 80,4 & 19,6 & 100 & \\
\hline
\end{tabular}




\section{Pembahasan}

Pada penelitian ini peran pengawas menelan obat (PMO) adalah kegiatan yang dilakukan oleh PMO sesuai dengan standar tugas PMO yang tertulis dalam Pedoman Diagnosis dan Penatalaksanaan Tuberkulosis di Indonesia dan Bahan Pelatihan Pengawas Menelan Obat. $^{6,7}$ Keberhasilan pengobatan pada penelitian ini merujuk kepada jumlah pasien TB paru dan ekstra paru yang sembuh dan pengobatan lengkap di Puskesmas Kecamatan Johar Baru tahun 2016. Hasil uji statistik penelitian ini menggunakan Chi Square didapatkan hasil $\mathrm{P}=1,000(\mathrm{P}>0,05)$, maka disimpulkan tidak ada pengaruh signifikan antara hubungan peran PMO terhadap keberhasilan pengobatan TB. Hasil penelitian ini sesuai dengan penelitian yang dilakukan oleh Erawatyningsih (2009) dan Nurmadya (2015) menyatakan bahwa tidak ada pengaruh yang signifikan peran PMO terhadap pengobatan TB. ${ }^{8,9} \mathrm{Hal}$ ini berbeda dengan yang didapatkan Nomi (2010) tentang hubungan kinerja PMO dengan kesembuhan pasien TB di Surakarta, dikatakan bahwa terdapat hubungan bermakna antara peranan PMO dengan kesembuhan pasien dengan nilai p-value 0,029. Perbedaan ini terjadi disebabkan oleh perbedaan waktu, tempat, populasi penelitian. ${ }^{10}$ Hasil penelitian ini menunjukkan bahwa peran PMO tidak berhubungan dengan keberhasilan pengobatan TB dikarenakan meskipun distribusi hasil PMO berperan dengan hasil pengobatan berhasil tinggi yaitu 32 orang, ditribusi hasil PMO tidak berperan dengan hasil pengobatan berhasil juga cukup banyak yaitu 13 orang. Hal ini sesuai dengan hasil penelitian yang dilakukan oleh Murtantiningsih (2010) di Puskesmas Purwodadi I Kabupaten Grobogan, hasil uji statistik menggunakan uji Chi Square di dapatkan $P$ value lebih besar dari 0,05 (0,773 $>0,05)$. Hal ini menyatakan bahwa tidak ada hubungan dukungan PMO dengan kesembuhan penderita TB paru dikarenakan distibusi responden yang menyatakan tidak ada dukungan PMO maupun ada dukungan PMO mempunyai perbedaan yang cukup kecil. ${ }^{11}$ Dalam penelitian ini faktor peran PMO dalam pengobatan penderita tidak ada pengaruh yang signifikan, karena setiap pasien TB mempunyai motivasi yang kuat untuk sembuh hal ini diungkapkan oleh masing-masing respoden. Pasien TB sudah mendapatkan informasi yang cukup mengenai penyakit nyaa dari dokter atau petugas kesehatan dari puskesmas. Pengobatan TB membutuhkan waktu yang lama, sehingga saat pengambilan obat dan cek dahak rutin, pasien TB akan diingatkan kapan pengambilan obat dan cek dahak selanjutnya, diberikan masker untuk mencegah penularan penyakit TB oleh petugas kesehatan.

Hal ini sesuai dengan hasil penelitian yang dilakukan oleh Murtiwi (2006) bahwa PMO lebih baik berasal dari petugas kesehatan. Penelitian tersebut menunjukkan bahwa tidak semua PMO menjalankan fungsinya dengan benar seperti mengingatkan minum obat pasien TB setiap hari. Sebenarnya sesuai dengan DOTS harus observasi langsung yaitu melihat dengan pasti bahwa obat telah diminum pasien. Sesuai dengan program pemberantasan penyakit TB yang menjadi PMO adalah lebih baik petugas kesehatan, tetapi temuan penelitian tersebut hanya sedikit petugas kesehatan yang menjadi PMO. Pasien berpendapat tidak perlu ada PMO karena keberadaan PMO selama ini tidak efektif. Hal ini menunjukkan bahwa pasien TB memiliki potensi untuk diberdayakan dengan memfasilitasi terbentuknya kelompok pasien TB atau self-help group. ${ }^{12}$

Pada penelitian ini terdapat beberapa keterbatasan, adanya keterbatasan dana dan waktu peneliti, sehinggga peneliti hanya melakukan penelitian pada pasien TB di Puskesmas Kecamatan Johar Baru tahun 2016 saja. Penetapan beberapa sampel tidak sesuai dengan hasil random sampling yang didapatkan oleh peneliti karena saat didatangi alamat responden tidak berada di rumah, responden sedang bekerja, atau pindah alamat. Pada beberapa responden mendapat intervensi keluarga saat mengisi kuesioner sehingga metode pengisian kuesioner peneliti ubah dari mengisi kuesioner sendiri oleh responden menjadi metode wawancara menggunakan kuesioner oleh peneliti. 


\section{Simpulan}

Berdasarkan hasil penelitian ini, tidak ada hubungan peran pengawas menelan obat (PMO) terhadap keberhasilan pengobatan tuberkulosis di Puskesmas Kecamatan Johar Baru Jakarta Pusat tahun 2016.

\section{Saran}

Bagi instansi kesehatan, petugas puskesmas, serta kader sebaiknya mengawasi pengawas menelan obat (PMO) dalam menjalankan tugasnya terhadap pasien TB. Hasil penelitian ini merupakan umpan balik bagi petugas kesehatan yang dapat digunakan untuk merencanakan dan menerapkan program promosi atau edukasi kesehatan pada pasien TB. Pasien TB memiliki potensi untuk diberdayakan dengan memfasilitasi terbentuknya kelompok pasien TB atau paguyuban TB (self-help group). Bagi keluarga pasien TB, sebaiknya lebih berperan aktif dalam memperhatikan keluarga yang terkena TB selama pengobatan intensif serta pengobatan lanjutan OAT sehingga dapat menyelesaikan pengobatan dan dinyatakan sembuh.

Bagi peneliti selanjutnya, apabila memiliki kecukupan dana dan waktu dalam melakukan penelitian dengan variabel sama diharapkan penelitian ini dapat diteliti lagi dengan tempat penelitian yang luas dan jumlah sampel yang lebih banyak serta menggunakan metode penelitian yang berbeda.

\section{Daftar Pustaka}

1. WHO. Global Tuberculosis Report 2015. Ed: 20 ${ }^{\text {th }}$. Geneva; 2015 [cited 2016 September 20]. Available from :http://apps.who.int/iris/bitstream/10665/ 191102/1/9789241565059_eng.pdf .

2. WHO. Global Tuberculosis Report 2016. Geneva: 2016 [cited 2016 Desember 31]. Available from http://apps.who.int/medicinedocs/docum ents/s23098en/s23098en.pdf.
3. Departemen Kesehatan RI. Riset Kesehatan Dasar 2013. Jakarta: Departemen Kesehatan RI. 2013.

4. Departemen Kesehatan RI. Profil Kesehatan Provinsi DKI Jakarta Tahun 2015 . Jakarta: Departemen Kesehatan RI. 2015.

5. Achmadi, U.F. Manajemen Penyakit Berbasis Wilayah, Jakarta: Kompas. 2005.

6. Perhimpunan Dokter Paru Indonesia. Pedoman Diagnosis dan Penatalaksanaan Tuberkulosis di Indonesia. 2006 [cited 2016 Oktober 5]. Available from: http://www.klikpdpi.com/konsensus/tb/t b.html.

7. PR TB-HIV Aisyiyah. Bahan Pelatihan Pengawas Menelan Obat (PMO). Jakarta. 2016.

8. Erawatyningsih, Erni., Purwanta, Heru Subekti. Faktor-faktor yang Mempengaruhi Ketidakpatuhan Berobat pada Penderita TB Paru. 2009.

9. Nurmadya, Irvan Medison, Hafni Bachtiar. Hubungan Pelaksanaan Strategi Directly Observed Treatment Short Course dengan Hasil Pengobatan Tuberkulosis Paru Puskesmas Padang Pasir Kota Padang 2011-2013. FK Universitas Andalas; 2015.

10. Andita, Puri Nomi. Hubungan kinerja pengawas minum obat (PMO) dengan kesembuhan pasien TB paru kasus baru strategi DOTS. Surakarta: Universitatas Sebelas Maret. 2010.

11. Murtantiningsih, Bambang Wahyono. Faktor-Faktor yang Berhubungan dengan Kesembuhan Penderita Tuberkulosis Paru. Jurusan Ilmu Kesehatan Masyarakat, Fakultas Ilmu Keolahragaan, Universitas Negeri Semarang. 2010.

12. Murtiwi. Keberadaan Pengawas Minum Obat (PMO) Pasien Tuberkulosis Paru di Indonesia. Jakarta: Staf Akademik Dasar Keperawatan dan Keperawatan Dasar FIK-UI. 2006. 